\title{
Development of Phaseolus vulgaris endogenous reference and Embrapa 5.1 event-specific assays for quantification of Embrapa 5.1 GM common bean using real time PCR
}

\author{
Diana Treml, Gustavo Venturelli, Fabio Brod, Ana Carolina Arisi Maisonnave*
}

From 5th Congress of the Brazilian Biotechnology Society (SBBIOTEC)

Florianópolis, Brazil. 10-14 November 2013

\section{Background}

Brazil is the second largest producer of genetically modified (GM) crops with 37 GM crop varieties approved by CTNBio for commercialization. One of these varieties is the Embrapa 5.1 common bean, resistant to the bean golden mosaic virus (BGMV). The Embrapa 5.1 event was developed using the RNAi concept to induce the silencing of the AC1 viral gene [1]. Labelling of food products containing GMOs in Brazil is mandatory [2], so methods for quantification of GMOs are required. Real time PCR methods have been used as the gold standard for GMO quantification. In a previous work, we have developed a construct-specific PCR detection assay for Embrapa 5.1 [3]. In this study we developed an event-specific PCR assay for Embrapa 5.1.

\section{Methods}

Genomic DNA was extracted from leaves using two different protocols, a CTAB method and the DNeasy Plant Mini Kit with modifications [3].

Quantification of the endogenous reference was performed using primers and Taqman probe targeting the lectin gene present in common bean (Phaseolus vulgaris) genome. The reaction parameters efficiency and limit of detection (LOD) were determined using conventional and GM varieties Perola and Pontal by 10 -fold serial dilution of the genomic DNA ranging from $10^{5}$ to $10^{0}$ genome copies. The assay specificity was performed using 50 accessions of Phaseolus vulgaris and 13 different crop species including maize, GM maize varieties, soybean and GM soybean RR.
Quantification of the event-specific fragment was performed using primers and probe targeting the event-specific junction of the Embrapa 5.1 event. The reaction parameters efficiency and limit of detection (LOD) were determined for the variety Perola GM by 10 -fold serial dilution of the genomic DNA ranging from $10^{5}$ to $10^{0}$ genome copies. The specificity assay was performed using the Embrapa 3.2 event, also resistant to the BGMV. Primers and probe concentrations were tested in order to determine the more suitable reaction efficiency.

\section{Results and conclusions}

The endogenous reference presented an efficiency of $96 \%$ and a LOD of 10 genome copies. This target was specific for the quantification of Phaseolus vulgaris varieties and no amplification was observed in 10 out of thirteen negative controls. The remaining three negative controls presented late $\mathrm{Cts}(\mathrm{Ct}>34)$. Also, this assay presented similar Cts among the fifty accessions of Phaseolus vulgaris.

The event-specific detection presented efficiencies ranging from 104 to $111 \%$. A LOD of 1 genome copy was obtained. Also, this assay was specific for the Embrapa 5.1, although four out of twelve reactions were positive for the Embrapa 3.2 event. Even so, these four amplification presented late $\mathrm{Cts}(\mathrm{Ct}>38)$. The primers and probes developed in this work are suitable for Taqman real time PCR quantification of Embrapa 5.1.

\section{Acknowledgements}

The work was financially supported by CNPq grant 471401/2012-9. D.T. is the recipient of a CNPq Master fellowship; G.L.V., a CAPES Master fellowship and F.C.A.B. a CAPES PNPD fellowship. 


\section{References}

1. Aragão FJ, Nogueira EO, Tinoco ML, Faria JC: Molecular characterization of the first commercial transgenic common bean immune to the Bean golden mosaic virus. J Biotechnol 2013, 166(1-2):42-50.

2. Regulates the information access concerning foods and ingredients containing or produced from genetically modified organisms. DOU Official Journal of Brazil, Brasilia, Brazil 2003, Brazil: Decree no. 4.680, April 24, 2003.

3. Dinon AZ, Brod FC, Mello CS, Oliveira EM, Faria JC, Arisi AC: Primers and probes development for specific PCR detection of genetically modified common bean (Phaseolus vulgaris) Embrapa 5.1. J Agric Food Chem 2012, 60(18):4672-4677.

doi:10.1186/1753-6561-8-S4-P116

Cite this article as: Treml et al.: Development of Phaseolus vulgaris endogenous reference and Embrapa 5.1 event-specific assays for quantification of Embrapa 5.1 GM common bean using real time PCR. BMC Proceedings 2014 8(Suppl 4):P116.

\section{Submit your next manuscript to BioMed Central} and take full advantage of:

- Convenient online submission

- Thorough peer review

- No space constraints or color figure charges

- Immediate publication on acceptance

- Inclusion in PubMed, CAS, Scopus and Google Scholar

- Research which is freely available for redistribution

Submit your manuscript at www.biomedcentral.com/submit
(Ciomed Central 